\title{
IMPROVING THE STUDENTS' WRITING SKILL THROUGH SEDONA METHOD
}

\author{
Nur Qalby \\ English Education Department, Faculty of Teacher Training and Education \\ Muhammadiyah University of Makassar \\ nurqalby@unismuh.ac.id
}

\begin{abstract}
The objective of this research was to find out the improvement of content and organization in writing skill by using Sedona Method at the Tenth Grade Students of SMA Batara, Gowa. The researcher used A Classroom Action Research (CAR). The Researcher had conducted two cycles, where each cycle consisted of four meetings. This classroom Action Research (CAR) was at The Eighth Grade of SMA Batara Gowa, Class $X B$. As subject in this research was the X Grade with students' number as about 29 students. The instruments were writing test and observation sheet. The application of Sedona Method can improve the students' writing especially in content and organization. This leads to conclusion that application of Sedona Method was needed in the English Language teaching and learning in improve their competence to organize their idea. Sedona Method that was focused on the learners can engaged the students to organize their ideas better than before. The findings of the research were (1) the students' content achievement was improved $9.98 \%$ from diagnostic test to cycle 1 and was improve $10.03 \%$ from cycle I to cycle II (2) the students' organization achievement was improve $8.63 \%$ from diagnostic test to cycle I and was improve $10.03 \%$ from cycle I to Cycle II. From the description above it could be conclude the improving of the students' writing skill in descriptive paragraph in terms of content and organization by using Sedona Method at the Tenth Grade of SMA Batara Gowa was improved.
\end{abstract}

Keywords: Writing Skill, Sedona Method

\section{INTRODUCTION}

Writing is a part of English language teaching beside of listening, reading, and speaking. Writing is admitted widely as one of the most difficult skills that students ever do, either in foreign language or in their native language. Writing is one of the hardest things that people do and writing is hard because it requires thinking.

Writing skill become important because writing help to refine ideas when you give others feedback. But the problem is how to refine ideas. Most of students argue writing is hard because they have no idea, and there are any reasons for that. The expand times and technology advance bring the positive impact in increasing educational in teaching and learning process, so that the teaching system always change into completing, particularly which related to their way of teaching. 
It is concerned with language learning and teaching, especially teaches of writing. Pressley and Block in Ryani (2010: 1) suggested teachers can learn by using strategy, how the strategies work and become better able to teach them to their own students by applying the strategies to their own writing. Some students seem naturally enthusiastic about learning, but many need or expect their instructions to inspire, challenge, and stimulate them.

According to McDonough, Steven (1981: 4-5) there are some things that may causing that problem. The first thing is students factors: here one might include motivation, intelligence, etc. the other things is teacher factors: relevant factor here how the teacher mode of control over the students, teaching style, etc, in order word how the teacher manage 1 ass from the starting until the end of class, how the teacher prevent outside disruption, and how the teacher have the attention of students, so the students' become more motivated in learning process. The next factors is social factors: here it might included the type of social atmosphere in the classroom, the size, composition, and the type of verbal interaction among teacher and pupil, the mixture of social background and level of ability in the classroom.

For teaching writing problem, it is important to teacher create best moment at the classroom. Direct students to enthusiastic to write topic that they have familiar topic and ask to students to reflect their own imagination into paper sheet. More important as teacher to make students comfortable with the idea that they will to write and developed.

The researcher decides to implement Sedona Method to enhance the students' writing skill. It will be held at the tenth grade students of SMA Batara Gowa. In the school, the researcher has found some problems which related to writing skill that is faced by the students, teacher in teaching style and classroom condition.

\section{SEDONA METHOD}

Sedona method is a technique in language teaching appropriate pattern for find out based problem, problem solving, and qualities by dissolve negative emotions to achieve the goals based on a series of underlying assumptions about 
how the mind works and how people act and interact. Defines of Sedona method related in Smart teaching that the method used of the teacher to create an attractive and pleasure study atmosphere in the classroom.

Hale Dwoskin and Lester Levinson (2005: 3) said Sedona Method is a technique gentle, powerful and revolutionary mind that releasing all negative thoughts, emotions and feeling. This technique generating developed by John Ginder and Richard Bandler (a graduate for students psychology) in Neurolinguistic programming were interested in how people influence each other and in how the behaviors of very effective people could be duplicated. They were essentially interested in discovering how successful communicators achieved their success. They studied successful therapist and concluded that they "followed similar patterns in relating to their clients and in the language they used, and that they all held similar beliefs about themselves and what they were doing" (Revell and Norman 1997:14).

Sedona method as a system of techniques therapists could use in building rapport with clients, gathering information about their internal and external views of the world and helping them achieve goals and bring about personal change.

Sedona method provides a theoretical framework and a set of working principle for directing or guiding therapeutic change, but the principles have been applied in a variety of other fields, including management training, communications, sales and marketing, and language teaching. Sedona method was not developed with any applications to language teaching in mind.

However, because the assumption refer to attitude to life, to people, and to self discovery and awareness, it has had some appeal within language teaching to those interested in what we have called humanistic approaches that is, approaches that focus on developing one's sense of self actualization and selfawareness, as well as to those drawn to what has been referred to as New Age Humanism.

The programming part of Sedona method is concerned with training ourselves to think, speak, and act in new and positive ways in order to release our potential and reach those heights of achievement which we previously only 
dreamt of. (Revell and Norman 1997: 14)

\section{Key Principles Characteristic of Sedona Method (O'Connor and McDermott 1996)}

According to this method, Sedona method is design an appropriate pattern for find out based problem, problem solving, and qualities. There are four aspect of characteristic Sedona method.

1 Outcomes: the goals or ends. Precisely what you want helps you achieve it. This principle can be expressed as 'know what you want'

2 Rapport: a factor that is essential for effective communications maximizing similarities and minimizing differences between people at a non conscious level. This principle can be expressed as "Establish rapport with yourself and then with others".

3 Sensory acuity: noticing what another person is communicating, consciously and nonverbally. This can be expressed as "Use your senses. Look at, Listen to, and feel what is actually happening".

4 Flexibility: doing things differently if what you are doing is not working: having a range of skills to do something else or something different. This can be expressed as "Keep changing what you do until you get what you want".

Presuppositions that guide application in language learning by Revell and Norman (1997). The idea is that these Principles become part of the belief system of the teacher and shape the way teaching is conducted no matter what method the teacher is using

5 Mind and body are interconnected. They are parts of the same system and each affects the other.

6 The map is not the territory: we all have different maps of the world.

7 There is no failure, only feedback..... and a renewed opportunity for success.

8 The map becomes the territory: what you believe to be true either is true or become true.

9 Knowing what you want helps you get it.

10 The resources we need are within us. 
11 Communications is nonverbal as well as verbal.

12 The non conscious mind is benevolent.

13 Communication is non conscious as well as conscious.

14 All behavior has a positive intention.

15 The meaning of my communication is the response I get.

16 Modeling excellent behavior leads to excellent.

17 In any system, the element with the greatest flexibility will have the most influence on that system.

As noted in Revell and Norman's (1997) teachers are expected to model their teaching on expert teachers they most admire. Similarly, learners are expected to find successful models for that person they themselves are striving to become: "if you want to be an excellent teacher, model excellent teachers. Look at that they do, how they act, what sort of relationship they have with their students and colleagues. Ask them how they feel about what they do. What are their beliefs? Second, positions them. Imagine what it's like to be them. As you learn techniques and strategies, put them into practice. Share modeling strategies with students. Set the project of modeling good learners. Encourage them to share and try out strategies they learn. If you want to speaks a language like a native speaker, model native speakers". (Revell and Norman 1997:116)

"Rapport principle is meeting other in their world, trying to understand their needs, their values and their culture and communicating in ways that are congruent with those values. You don't necessarily have to agree with their values, simply recognize that they have a right to them and work within thei framework, not against it”. (Rylatt and Lohan 1995:121).

Rylatt and Lohan give the following example of how a teacher might apply rapport in responding to the following statements from students.

1. I hate this stuff. It's such a waste of time.

2. Everyone says that. It makes me sick.

3. I can't do it.

4. This is all theory.

In establishing rapport, the teacher could respond:

1. Is a part of you saying that you want to be sure your time is well spent 
today?

2. Who says that

3. What, specifically, can't you do?

4. Are you saying you want practical suggestions?

Likewise, principle 10 above "All behavior has a positive intention". Would lead the teacher to seek for a positive intent in the following situations.

1. A learner disagree strongly with the teacher

2. A students frequently comes late to class

3. A student seeks to dominate discussions.

The possible positive intents here could be:

1. Wanting to have expertise acknowledged

2. Having other important priorities.

3. Needing to vocalize thoughts in order to internalize them.

\section{The Advantages of Sedona Method}

This method has some advantages of the research.

a. According to Dwoskin says the best thing a student can do in addition to studying is to release the stress and the anxiety and whatever else is distracting them from doing what they need to do in order to learn what they need to learn.

b. Enjoyable.

c. Sedona method will improve memory, concentration, and creativity.

d. Sedona method helps the students to absorb, and process information more quickly and easily.

e. Useful in problem solving and brainstorming endeavors.

f. The technique supports you in quickly shifting your state of consciousness from one of stress and resistance to one of relaxations and allowance

\section{Steps of the Model to be followed in the Classroom}

Procedure that can followed in the classroom as follows:

1 Students are told that they are going on an inner experience as you eat a biscuit 
2 Check that they understand vocabulary of the experience (smell, taste, chew, swallow, bite, lick, etc)

3 Students are asked to relax, and go inside. Once inside, they listen to the teacher-produced fantasy, which is given as the following:

4 (An abbreviated version of the teacher text)" Imagine a biscuit. A delicious biscuit. The sort you really like. Pick it up and look at it closely. Notice how your mouth is beginning to water. In a moment you are going to eat the biscuits. Say the words to yourself: I am going to eat this biscuits'. Slowly chew the biscuits and notice how delicious it tastes on your tongue and in your mouth. Say the world to you I'm really enjoying eating this biscuits. Notice how you feel now. Notice the taste in your mouth. Notice how your stomach feels with a biscuits inside it. Notice how you feel emotionally. You have eaten a biscuits. How you are feeling now? Think of the words to describe how you are feeling now.

\section{Evaluation}

Ask for the students to describe how they are feeling. The feelings write down on the paper. Then ask the students to stand in front of class to read the text and the teacher check the content of story, identified is it idea relevance and coherence in text.

Sedona method does not consist of a set of techniques for teaching a language based on theories and assumption at the levels of an approach and a design. Rather it, it is a humanistic philosophy and a set of beliefs and suggestions based on popular psychology, designed to convince people that they have the power to control their own and other people's for better.

In language teaching, the appeal to some teachers stems from the fact that it offers a set of humanistic principles that provide either a new justifications foe well known techniques from the communicative or humanistic repertoire or a different interpretation of the role of the teacher and the learner, one in harmony with many learner centered, person centered views. 


\section{CONCEPT OF WRITING}

\section{Definition of Writing}

Writing is basic skills that can be developed by everyone through application and practice. It is the way to express an idea, opinion, science or to introduce one's culture to another country, etc. some have different definition about writing.

According to Lado (2006:23) in Riyatun says that writing is also a form of thinking, but it is thinking for particular audience and for a particular occasion. It is a tool like diagrams, maps, or numerical calculation for thinking with and for organizing ideas in sequences and systems that cannot easily be held simultaneously in the mind. When we write, we do not only have to keep our purposes in writing our mind, but we also have to think about the facts, opinions, or ideas that are relevant to our purposes and think about how to organizing them in the compositions. We also have to consider that a good piece of writing has some characteristics such as coherence, cohesion, unity, and completeness. Writing does not occur without any rule and meaning.

According to Clark (1986:3) in Riyatun writing is a good piece of writing has some characteristics such as coherence, cohesion, unity, and completeness. Writing is an activity of immediate self-expression, in which we put out ideas spontaneously and inspirationally. Furthermore, writing is a process of composition in the sense of making or building which involves constant reconstruction.

Kroma (1988:3) argues that writing is kind of activity where the researcher express all the ideas in his mind in the paper (print) from word to sentence and sentences to paragraph and from paragraph to essay.

\section{The Types of Writing Performance}

Brown in Ryani (2010) describes that there are four categories of writing skill area. Those four categories are as follows:

\section{1) Imitative Writing}


This category includes the ability to spell correctly. The students have to attain skills in the fundamental, basic tasks of writing letters, words, punctuation, and very brief sentences.

\section{2) Intensive (Controlled) Writing}

In this category, most assessment tasks are more concerned with a focus on form, and are rather strictly controlled by the text design. The students have to attain skills in producing appropriate vocabulary within a context, collocation, idioms, and correct grammatical features up to the length of a sentence.

\section{3) Responsive Writing}

This level requires the students to perform a limited discourse level, creating logically connected sequence of two or three paragraphs. It is more focused on the discourse conventions that will achieve the objectives of the written text. It has strong emphasis on context and meaning.

\section{4) Extensive Writing}

Extensive writing implies successful management of all the processes and strategies of writing for all purposes, such as an essay, a term paper, a thesis, etc. The writers focus on achieving a purpose, organizing and developing ideas logically, using details to illustrate ideas, demonstrating syntactic and lexical varieties, and so on. This level is usually for advanced learners.

\section{The Characteristic of Good Writing}

We want the readers will love to read our composition by using exact words, fresh ideas and right in linguistic. In making a good writing is not easy as we write sentences that have meaningless. A good writing always present ideas that are fresh and original. It is not boring and always keeps our interest because we use the right language, appropriate words and free of serious errors in grammar.

Adelstein and Prival (1980) state some characteristics of the good writing as follows:

a. Good writing reflects the researchers ability to use the appropriate voice even thought all good writing the sound and someone talking to someone else, the 
voice heard thought the writing must also suit with the someone and audience of the occasion.

b. Good writing reflects the researcher's ability to organize the material into a coherent writing so that it moves logically from a central, dominant idea to supporting points and finally to consistent ending conveying to the reader a sense of a well thought out plan.

c. Good writing reflects the researcher's ability to write clearly and unambiguously, to use sentence structure, language, and example so that the one possible meaning is the researcher's intended one.

d. Good writing reflects the researcher's ability to write convincingly to interest readers in the subject and to demonstrate a though and sound understanding of it.

e. Good writing reflects the researcher's to citizen the first draft and revises it. Revision is the key of effective writing.

\section{RESEARCH METHODOLOGY}

The research was conducted at the Tenth Grade Students of SMA Batara Gowa, class X.b on November - December 2012. This research schedule was determined based on the school academic calendar. The aim of this research was to improve the students' in writing descriptive paragraph through Sedona Method. The steps of the research are preliminary observation, planning, and implementation, observing, and reflecting. This research was held in two cycle, they were cycle I and cycle II. Every cycle was needed four meetings to finish it but the cycle II was taken if the result of cycle I was not significant.

\section{FINDINGS AND DISCUSSION}

\section{A. Findings}

1. The improvement of the students' writing descriptive paragraph based on the content aspect 
The improvement of the students' writing proficiency based on the content aspect by using Sedona method in Diagnostic Test, cycle I and Cycle II describe in the following table.

Table 1. The improvement of the students' writing descriptive paragraph based on content aspect

\begin{tabular}{|c|c|c|c|c|c|c|c|}
\hline \multirow[b]{2}{*}{ No. } & \multirow[b]{2}{*}{ Indicators } & \multirow{2}{*}{$\begin{array}{l}\text { D-Test } \\
\text { Mean } \\
\text { Score }\end{array}$} & \multirow{2}{*}{$\begin{array}{c}\text { C- I } \\
\text { Mean } \\
\text { Score }\end{array}$} & \multirow{2}{*}{$\begin{array}{l}\text { C- II } \\
\text { Mean } \\
\text { Score }\end{array}$} & \multicolumn{3}{|c|}{ Improvement (\%) } \\
\hline & & & & & $\begin{array}{c}\text { DT- } \\
\text { CI }\end{array}$ & $\begin{array}{l}\text { CI- } \\
\text { CII }\end{array}$ & $\begin{array}{l}\text { DT- } \\
\text { CII }\end{array}$ \\
\hline 1 & Unity & 50.34 & 60.00 & 70.34 & 9.66 & 10.34 & 20.00 \\
\hline 2 & Completeness & 51.7 & 62.0 & 71.72 & 10.3 & 9.72 & 20.02 \\
\hline & $\sum=$ & 102.04 & 122.0 & 142.06 & 19.96 & 20.06 & 40.02 \\
\hline & $\mathrm{X}$ & 51.02 & 61.0 & 71.03 & 9.98 & 10.03 & 20.01 \\
\hline
\end{tabular}

The table above shows that the students' mean score of writing descriptive paragraph based on the content aspect from diagnostic test to cycle I and cycle II, which in diagnostic test the students' score achievement in writing content aspect is 51.02. After evaluation in cycle I the students' mean score becomes 61.0. So the improvement of the students' writing descriptive paragraph based on the organization aspect from diagnostic test to cycle $\mathrm{I}$ is $9.98 \%$. There is also significant improvement of the students' writing content from cycle I to cycle II where the students' writing descriptive paragraph based on the content aspect in cycle I is 61.0 and in cycle II is 71.03. So the improvement of students' writing descriptive paragraph based on content aspect achievement from cycle I to cycle II is $10.03 \%$. The students' improvement from diagnostic test to cycle II is $20.01 \%$. Assessment of cycle II is greater than cycle I (71.03 > 61.03). Therefore, the improvement of organization from diagnostic to cycle II is $(20.01 \%>9.98 \%)$. So, this shows there is a significant improvement of students' in cycle I and cycle II through Sedona method.

To see the clearly the improvement of the students' writing skill based on explanation above: 
Figure 1: The scores classification of the students' writing descriptive paragraph based on content aspect

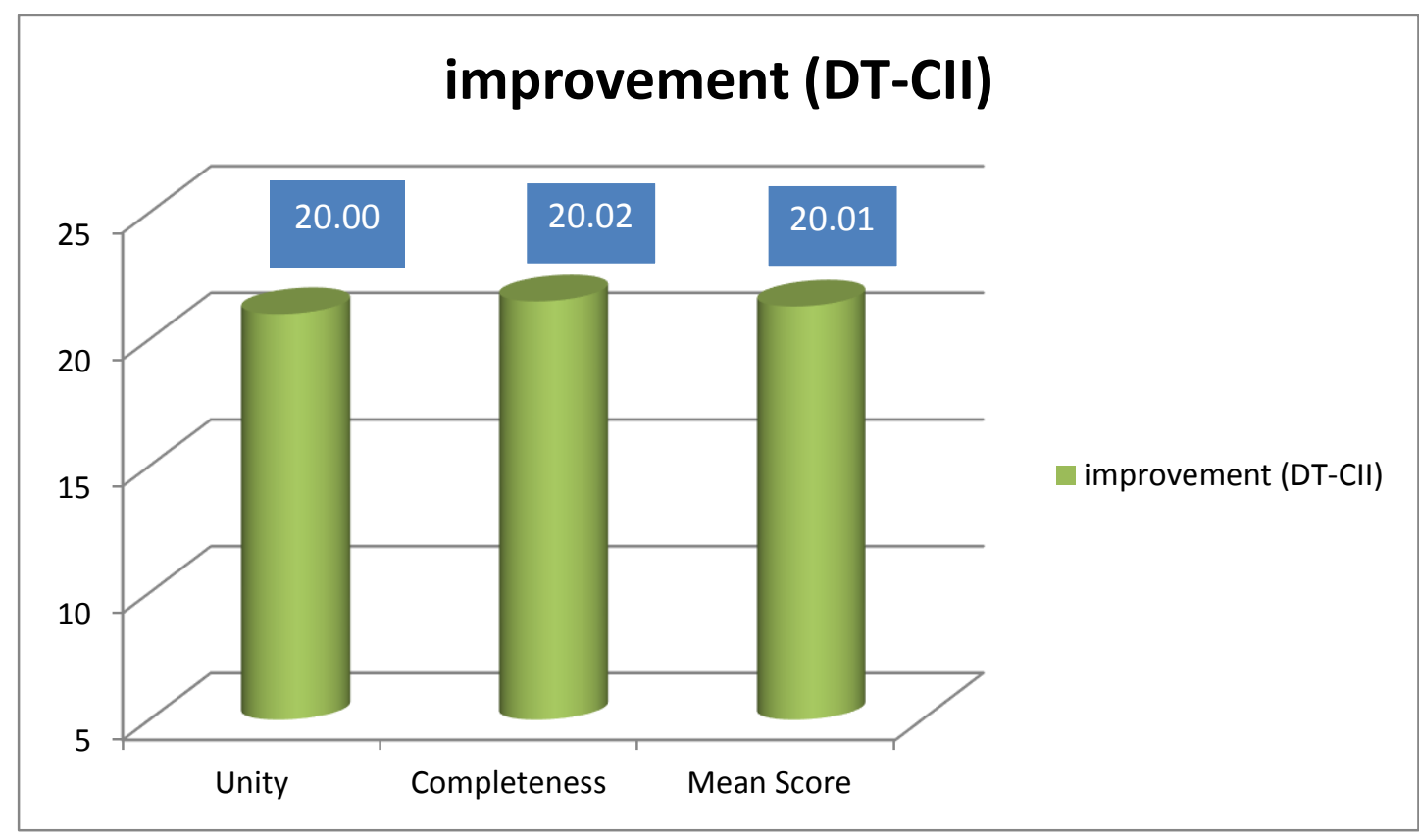

The chart above shows that the improvement of the students' writing in descriptive paragraph based on the content aspect which in diagnostic test to cycle II. In unity aspect the students' get achievement (20.00\%), and in completeness aspect the students' get (20.02\%). So, the assessment of students' score in content aspect is $20.01 \%$

2. The improvement of the students' writing descriptive paragraph based on the organization aspect

The application of Sedona Method in writing descriptive paragraph, the writer found that the mean score of organization is dealing with coherence and spatial pattern. The improvement of the students' writing organization dealing with coherence and spatial pattern at the Tenth Grade of SMA Batara Gowa can be seen clearly in the following table below: 
Table 2: The improvement of the students' writing descriptive paragraph based on the organization aspect

\begin{tabular}{|c|c|c|c|c|c|c|c|}
\hline \multirow[b]{2}{*}{ No. } & \multirow[b]{2}{*}{ Indicators } & \multirow{2}{*}{$\begin{array}{l}\text { D-Test } \\
\text { Mean } \\
\text { Score } \\
\end{array}$} & \multirow{2}{*}{$\begin{array}{c}\text { C- I } \\
\text { Mean } \\
\text { Score }\end{array}$} & \multirow{2}{*}{$\begin{array}{l}\text { C-II } \\
\text { Mean } \\
\text { Score }\end{array}$} & \multicolumn{3}{|c|}{ Improvement (\%) } \\
\hline & & & & & $\begin{array}{c}\text { DT- } \\
\text { CI } \\
\end{array}$ & $\begin{array}{l}\text { CI- } \\
\text { CII } \\
\end{array}$ & DT-CII \\
\hline 1 & Coherence & 50.34 & 60.00 & 70.34 & 9.66 & 10.34 & 20.0 \\
\hline 2 & $\begin{array}{l}\text { Spatial } \\
\text { Pattern }\end{array}$ & 53.7 & 61.3 & 71.03 & 7.6 & 9.73 & 17.33 \\
\hline & $\sum=$ & 104.04 & 121.3 & 141.37 & $\mathbf{1 7 . 2 6}$ & 20.07 & 37.33 \\
\hline & $\mathbf{X}$ & 52.02 & 60.65 & 70.68 & 8.63 & $\mathbf{1 0 . 0 3}$ & 18.66 \\
\hline
\end{tabular}

The table above shows that the students' mean score of writing descriptive paragraph based on the organization aspect from diagnostic test to cycle I and cycle II, which in diagnostic test the students' score achievement in writing organization aspect is 52.02. After evaluation in cycle I the students' in organization aspect becomes 60.65 . So the improvement of the students' writing descriptive paragraph based on the organization aspect from diagnostic test to cycle $\mathrm{I}$ is $8.63 \%$. There is also significant improvement of the students' writing organization from cycle I to cycle II where the students' writing descriptive paragraph based on the organization aspect in cycle $I$ is 60.65 and in cycle II is 70.68. So the improvement of students' writing descriptive paragraph based on organization aspect achievement from cycle I to cycle II is $10.03 \%$. The students' improvement from diagnostic test to cycle II is $18.66 \%$. Assessment of cycle II is greater than cycle I (70.68 > 60.65). Therefore, the improvement of organization from diagnostic test to cycle II is $(18.66 \%>8.63 \%)$. So, this shows there is a significant improvement of students' in diagnostic test, cycle I and cycle II through Sedona method.

To see clearly the improvement of the students' writing skill based on explanation above: 
Figure 2: The scores classification of the students' writing descriptive paragraph based on organization aspect

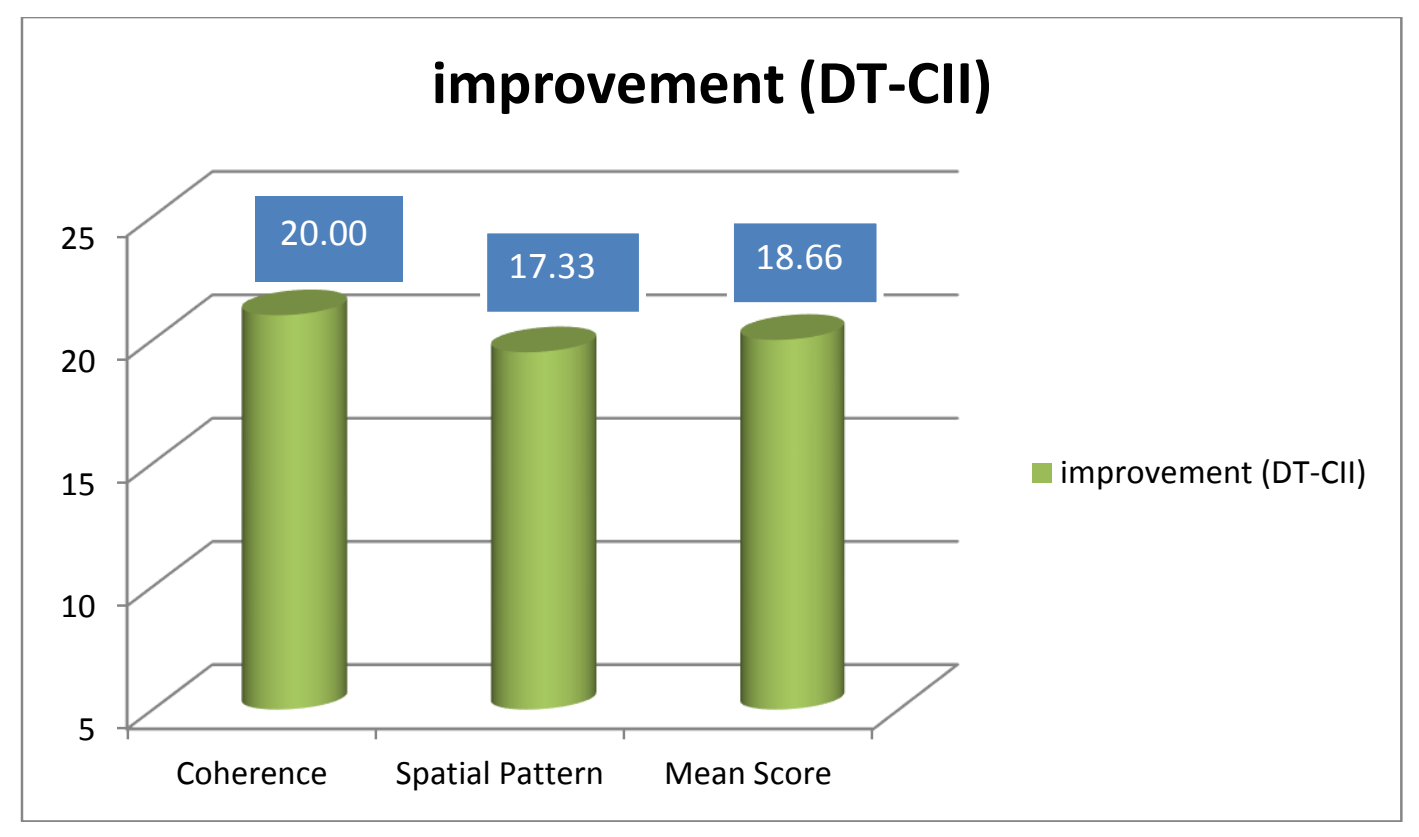

The chart above shows that the improvement of the students' writing in descriptive paragraph based on the organization aspect which in diagnostic test to cycle II. In coherence aspect the students' get achievement (20.00\%), and in spatial pattern aspect the students' get (17.33\%). So, the assessment of students' mean score in organization aspect is $18.66 \%$

\section{The result of the students' writing achievement in descriptive text}

The result of observation sheet of the students' achievement in teaching and learning process toward the use Sedona Method in improving the students' in writing descriptive paragraph at the Tenth Grade of SMA Batara Gowa which is conducted in two cycles during 8 meetings were taken by observer through observation sheet. It can be seen clearly through the following table:

Table 3: The Students Improvement in Writing Descriptive Text

\begin{tabular}{|c|c|c|c|c|c|c|c|}
\hline \multirow[b]{2}{*}{ No. } & \multirow[b]{2}{*}{ Indicators } & D-Test & C- I & C- II & \multicolumn{3}{|c|}{ Improvement (\%) } \\
\hline & & $\begin{array}{l}\text { Mean } \\
\text { Score }\end{array}$ & $\begin{array}{l}\text { Mean } \\
\text { Score }\end{array}$ & $\begin{array}{l}\text { Mean } \\
\text { Score }\end{array}$ & $\begin{array}{l}\text { DT- } \\
\text { CI }\end{array}$ & $\begin{array}{l}\text { CI- } \\
\text { CII }\end{array}$ & $\begin{array}{l}\text { DT- } \\
\text { CII }\end{array}$ \\
\hline 1 & Content & 51.02 & 61.00 & 71.03 & 9.98 & 10.03 & 20.01 \\
\hline 2 & Organization & 52.02 & 60.65 & 70.68 & 8.63 & 10.03 & 18.66 \\
\hline & $\sum=$ & 103.04 & 121.65 & 141.71 & 18.91 & 20.06 & 38.67 \\
\hline & $X$ & 51.52 & 60.8 & 70.8 & 9.45 & 10.03 & 19.33 \\
\hline
\end{tabular}


The table above indicates that the improvement of the students' writing descriptive text from the diagnostic test, first cycle and the second cycle is different. After evaluation in the diagnostic test (51.52) categorized poor, first cycle the students' writing becomes (60.8) and categorized as fair and the second cycle (70.8) which is categorized as good. The improvement of students' writing skill achieve from diagnostic to cycle I is $9.45 \%$, the first cycle to the second cycle $10.03 \%$ and diagnostic test to cycle II is $19.33 \%$. Assessment of cycle II is greater than from cycle I $(70.8>60.8)$ it is classified as good which means there is improvement of the students' writing skill and the improvement from diagnostic test to cycle II is greater than from diagnostic test to cycle I $(19.33 \%>9.45 \%)$. The table above proves that use of Sedona Method in teaching and learning process is able to improve the students' writing skill after taking action in the first cycle and the second where the students' achievement in cycle II is higher than the first cycle.

To see the clearly the improvement of the students' writing skill based on explanation above

Figure 3: The Improvement of the Students' Writing Descriptive Text.

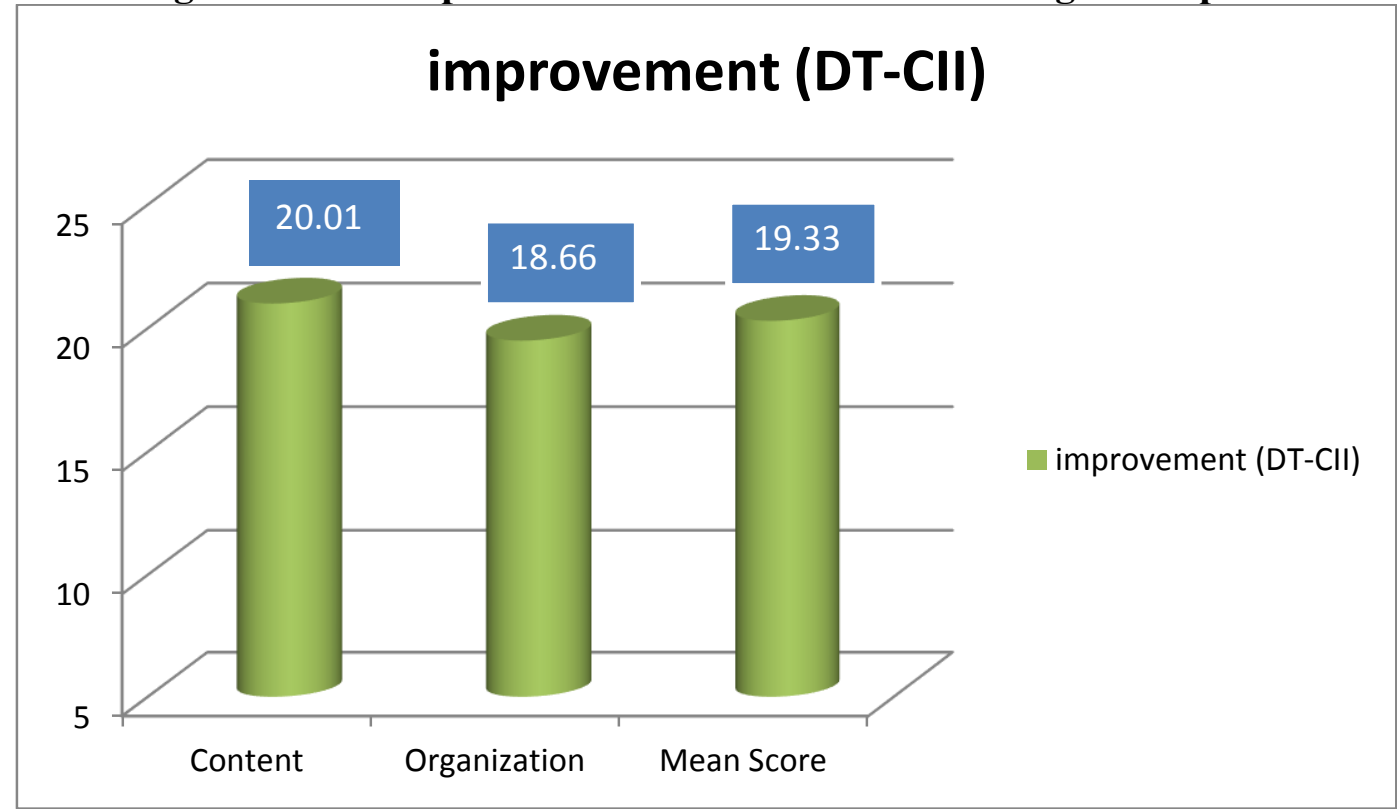

The chart above shows that the improvement of the students' writing in descriptive paragraph based on the content aspect which in diagnostic test to cycle II. In content aspect the students' get achievement (20.01\%), and in 
organization aspect the students' get (18.66\%). So, the assessment of students' score in content aspect is $19.33 \%$

\section{B. Implementation of Sedona Method}

The result of observation of students' activeness in teaching and learning process toward the implementation of Sedona Method to improve writing skill dealing with content and organization at the tenth grade of SMA Batara Gowa which is conducted in 2 cycels during 8 meetings is taken by the observer through observation sheet. In the cycle I has categorized fair but after conducting cycle II become good.

The implementation of Sedona Method starts from the beginning until the end after knowing the result of score students' in write descriptive text at the diagnostic test. The main of research is how the students can write descriptive text, and concern in content and organization of text. At the based theory of Sedona method, the researcher as successful communicator and create smart teaching to make the students interested.

The researcher creates enjoyable between a researcher and students or conversely. Agree with the hardest things that people do to write because requires of thinking. The problem is how to refine ideas. The ideas can refine if the students feels enjoy, they can imagine or thinking what they want to write. Then, the researcher chooses the familiar theme to help them in write descriptive text. It is also motivated the students' to write descriptive text.

Based on the conclusion above, we can indicate that the use of Sedona method can improve the students' writing skill in terms of content and organization. It can be shown of the students' mean score in writing from D-test to cycle I until cycle II.

\section{Discussions}

Based on the problem statements, the writer answered question in problem statements. Sedona Method can improve of content and organizations in writing skill at descriptive paragraph. The programming of Sedona Method is concerned with training ourselves to think and act, gathering information about their internal and external views. Related with objective of the study, the students' of SMA. Batara Gowa can improve writing skill through Sedona method for measured in 
connection with content, should be unity and completeness and organization material in writing involves coherence and spatial pattern. The parts element of writing as follow:

\section{Content}

The students' writing mean score in content based on the elements of unity and completeness by using Sedona Method is affect that were effective students' proficiency to write good paragraph. In the diagnostic test of content, the students' just could get means score is 51.02 in classified poor, it means that it was a far from the target. The paragraph is taught in the cycle I through Sedona Method in the class. The students' had difficulties in writing paragraph especially in content idea and expressing of develop their idea into written form. Then, the content that they wrote in their writing was not clear to the reader. And the students' could get means score 61.00 classified fair in cycle I.

The difficulty of the students' in writing had been analyzed. Finally, decided explain more clearly about descriptive paragraph through Sedona method. So, the research continued in cycle 2 by doing the revision in the lesson plan which prepared in revision planning of cycle 2 .

The result of revision planning to resolve the students' difficulties in getting ideas was in pre writing activity the researcher gave them familiar topic then they had to choose one of them, beside that also explain how to refine the ideas . It was done to avoid the reception in learning and teaching process. Finally, the students' could get means score 71.03 classified good in cycle II, and the researcher did not continue to cycle III because the result was good.

\section{Organization}

The implementation of extended writing project assessment in the class, the researcher found that the mean score in D-test was could get 52.02 it is classified poor, in the cycle I the students' just got means score 60.65 it is classified fair and in cycle II the students could get means score was 70.68 it is classified good, meanwhile the target was good it means that the target score could be archived in the cycle II.

The paragraph is taught in cycle I by using Sedona Method because the students' had difficulty to organize well their idea in form of paragraph and they 
are not have skill in organization elements of writing. When they wrote paragraph the first sentence and the next sentence was not connected.

Paragraph consist of topic sentence, supporting sentence and concluding sentences but the students' cannot makes all the supporting sentence and connect their paragraph so their paragraph still make confused the reader. The ideas that their write is not understood.

Based on the unsuccessful teaching in cycle I. Next step, lesson plan is continued in cycle II. Where, revised the lesson plan about the steps of a good paragraph that should explain more clearly. If needed, gave the students' occasion to ask about the material. Besides that, give better guidance for the students' in organizing their ideas.

\section{The students' mean score}

The students' writing mean score based on the elements of organization and content in diagnostic is 51.52 , cycle $\mathrm{I}$ is 60.8 and in the cycle II is 70.8 , it means that the mean score got improved from diagnostic to cycle I as $9.45 \%$, cycle I to cycle II got $10.03 \%$ and diagnostic to cycle II got 19.33 , it means that the target that had been said in the chapter I could be achieved. The writer may say that teaching writing descriptive paragraph by using Sedona Method, is a good way to improving the students' writing proficiency.

\section{CONCLUSION}

Based on the research findings and discussions in the previous chapter, the following conclusions are presented:

1. Sedona method can improve the students' writing skill to write descriptive paragraph. In content aspect, the students' avoid difficulties in write idea and expressing of develop their idea into written form. It is proved by improvement data from diagnostic test to cycle II is $20.01 \%$

2. Sedona method can improve the students' writing skill to organize paragraph in descriptive text. The students avoid difficulty to organize their idea in form of paragraph. It is proved by improvement data from diagnostic test to cycle II in organization aspect is $18.66 \%$ 
3. Sedona method is a good way to improve the students' writing proficiency based on content and organization. It is proved by improvement data from diagnostic to cycle II is $19.33 \%$.

4. Implementation of Sedona method can improve students' in writing skill in term of content and organization. Students' can refine ideas and they can imagine what they want to write and write is does not hardest things that students' do.

\section{BIBLIOGRAPHY}

Adelstein. M, E, Prival 1980. The Writing Commitment, $2^{\text {nd }}$ edition New York: Harcourt Brace Jovanovich. Inc.

Bandler, R.,and J. Grinder. 1982. Reframing: NLP and the Transformation of Meaning. Utah: Real People Press.

Brown in Ryani (2010). Logical Division of Idea. Thesis UIN.

Clark in Riyatun. (1986:3). Developing Student's Narrative Writing through Fairy Tales. Thesis UNNES.

Dwoskin, Hale. 2005. The Insider Guide to the Sedona Method. From www. Sedona.com. Retrieved August 12, 2012.

Georgia High School Writing Test. 2011. Georgia High School Writing

Rubric. From archives.doe.k12.ga.us/...aspx/GHSWT\%20rubrics.pdf.

Retrieved on December $21^{\text {th }} 2012$.

Gerrot, L. and Wignel, P. 1994. Making Sense of Functional Grammar. New South Wales: Antipodean Educational Enterprises (AEE).

Hornby, A.S. 1995. Oxford Learner's Dictionary. New York: Oxford University Press.

Jusrana. 2012. Improving students' Proficiency in Writing Descriptive Paragraphs through Scaffolding Strategy at Class VIII B Students of SMP Saribuana Makassar. Thesis Unismuh

Kroma Sk. 1988. "Action Research in Teaching Composition”. English Teaching forum Vol. XXVI. 
Lado in Riyatun. (2006:23). Developing Student's Narrative Writing through Fairy Tales. Thesis UNNES.

Mayer, Stephanie. 1992. The Process of Writing Activity, Nirvana Published. McDonough, Steven in Darwis. 2010. Management Classroom. Thesis UIN

O’connor, J., and I. McDermott. 1996. Principles of NLP. London: Thorsons.

Oshima, Alice and Hogue, Anna. 1998. Writing Academic English Fourth Edition. Longman.

Pressley and Block in Darwis. 2010. Management Classroom. Thesis UIN

Rajab, Abdul. 2008. Increasing Students' Writing Ability though Free Topic at the First Year Students of MAN 2 Model Makassar. Thesis UNISMUH

Rahman Ryani. 2010. Logical Division of Idea. Thesis UIN.

Ratnawati. 2012. The use of the English Writing Tasks to Train the Students' Writing Skills at Class XI of SMA. Muhammadiyah 1 Patongko, Sinjai. Thesis Unismuh.

Richard, Jack. 2001. Approaches and Methods in Language Teaching. Cambridge University Press.

Riyatun. 2006. Developing Student's Narrative Writing through Fairy Tales. Thesis UNNES.

Rylatt, A., and K. Lohan. 1995. Creating Training Miracles. Sydney: Prentice Hall.

Schwegler in Riyatun. 2006. Developing Student's Narrative Writing through fairy tales. Thesis UNNES.

Tenri A, A. Hj. 2012. Penelitian Tindakan Kelas. Makassar: seminar. 